\title{
Mesenchymal stem cells in the treatment of osteonecrosis of the jaw
}

\author{
Gianfilippo Nifosì ${ }^{1}$, Lorenzo Nifosì ${ }^{2}$, Antonio Fabrizio Nifosi ${ }^{3}$ \\ ${ }^{1}$ Department of Oncology and Hematology, VSHA Fondation, Passy, ${ }^{2}$ Santé Dorée Dental Clinic, Paris, French, \\ ${ }^{3}$ Smart Dental Clinic, Milan, Italy
}

\begin{abstract}
J Korean Assoc Oral Maxillofac Surg 2021;47:65-75)
Medication-related osteonecrosis of the jaw (MRONJ) has recently associated to the increase in antiresorptive and anti-angiogenic drugs prescriptions in the treatment of oncologic and osteoporotic patients. The physiopathogenesis of MRONJ remains unclear and available treatments are unsatisfactory. Newer pharmacological treatments have shown good results, but are not curative and could have major side effects. At the same time as pharmacological treatments, mesenchymal stem cells (MSCs) have emerged as a promising therapeutic modality for tissue regeneration and repair. MSCs are multipotential non-hematopoietic progenitor cells capable to differentiating into multiple lineages of the mesenchyme. Bone marrow MSCs can differentiate into osteogenic cells and display immunological properties and secrete paracrine anti-inflammatory factors in damaged tissues. The immunomodulatory, reparative, and anti-inflammatory properties of bone marrow MSCs have been tested in a variety of animal models of MRONJ and applied in specific clinical settings. The aim of this review is to discuss critically the immunogenicity and immunomodulatory properties of MSCs, both in vitro and in vivo, the possible underlying mechanisms of their effects, and their potential clinical use as modulators of immune responses in MRONJ, and to identify clinical safety and recommendations for future research.
\end{abstract}

Key words: Osteonecrosis, Bone regeneration, Mesenchymal stem cell, Cell therapy

[paper submitted 2020. 8. 23 / revised 1st 2020. 10. 19, 2nd 2020. 11. 4, 3rd 2020. 11. 8 / accepted 2020. 11. 10]

\section{Introduction}

Medication-related osteonecrosis of the jaw (MRONJ), originally described by Marx ${ }^{1}$ in 2003, was defined in 2014 by the American Association of Oral and Maxillofacial Surgeons (AAOMS) ${ }^{2}$ as being indicated by the presence of three criteria:

- Current or previous treatment with antiresorptive or antiangiogenic agents;

- Presence of exposed bone or probed bone through an intraoral or extra-oral fistula in the maxillofacial region for at least eight weeks; and

- No history of radiotherapy or evident metastatic disease

\footnotetext{
Gianfilippo Nifosì

Department of Oncology and Hematology, VSHA Fondation, 74700

Sallanches, France

TEL: +33-457474100

E-mail:g.nifosi@tin.it

ORCID: https://orcid.org/0000-0003-4329-6297

(c) This is an open-access article distributed under the terms of the Creative Commons Attribution Non-Commercial License (http://creativecommons.org/ licenses/by-nc/4.0/), which permits unrestricted non-commercial use, distribution, and reproduction in any medium, provided the original work is properly cited. Copyright (C) 2021 The Korean Association of Oral and Maxillofacial Surgeons. All rights reserved.
}

of the jaw.

The incidence ranges from $0.028 \%$ to $18.6 \%$, depending on the study population, sample size, and reasons for treatment ${ }^{3}$. In osteoporosis patients treated with oral amino bisphosphonates (BPs) the risk of MRONJ is $0.1 \%$, but in cancer patients treated with nitrogen-BPs or denosumab it is $1 \%$. The risk factors are various: treatment with BPs, especially nitrogenBPs (zoledronate, pamidronate, and ibandronate) or denosumab; drug dosage and time of treatment; glucocorticoids or chemotherapy; tooth extractions; dental or periodontal disease or dental trauma; smoking, anemia, diabetes mellitus, and obesity.

MRONJ is a disease affecting quality of life for which there is no standard treatment. Normally the treatment is conservative. The protocol involves the use of chlorhexidine mouthwashes and antibiotics (amoxicillin-clavulanate, clindamycin, or levofloxacin), while re-evaluating the patient every 15 days. If the condition does not improve or there is significant necrosis, the treatment is surgical, ranging from minimally invasive surgery to remove exposed bone areas to resective mandibular surgery followed by plate fixation with or without bone reconstruction. But only $35 \%$ of patients are treated with this procedure, so MRONJ is currently a 
complex disease with a pathogenesis that has not been fully clarified and that remains incurable. Therefore, new treatment strategies have been investigated in recent years ${ }^{4}$. Cell therapy and tissue engineering are potential therapeutic options. In a systematic review of the use of autologous platelet concentrates (APC) for the treatment of MRONJ, no significant differences between outcomes of surgical management with or without APC in $\mathrm{MRONJ}^{5}$ were observed.

Mesenchymal stem cells (MSCs) were first identified 40 years ago and described as a population of non-phagocytic medullary cells adhering to plastic, with fibroblast-like morphology capable of differentiating in vitro into bone, cartilage, adipose tissue, tendon, and muscle ${ }^{6}$. They demonstrate chemotactic and migration capacity at sites of inflammation and cell damage, as well as secretion of paracrine factors with anti-inflammatory and immuno-regulatory capacity ${ }^{7}$ that make them ideal candidates for cell therapy programs, especially at bone level.

MSCs have been extensively studied for multiple clinical applications. Cell therapy ${ }^{8}$ and tools to identify new molecular targets that favor bone reconstruction in osteonecrosis ${ }^{9,10}$ are the subject of this review.

\section{Methodology}

We conducted an electronic search of scientific articles and textbooks using PubMed, Cochrane Library, Medscape, and
Google Scholar from 1990 to the present, applying the "Full Text" filter.

The key words used were: osteonecrosis of the jaw, MSCs, cellular therapy, regenerative medicine.

Inclusion criteria:

- Articles published from the year 1990

- Articles in English

- Clinical trials

- Original articles

- Letters to the editor

Exclusion criteria:

- Articles published before 1990

- Articles in languages other than English

- Studies on injuries not due to drugs

\section{Results}

\section{Animal studies}

The results of animal studies are summarized in Table 1.

A murine osteonecrosis of the jaw (ONJ) model can be obtained using intravenous infusions of zoledronate (Zol) 125 $\mu \mathrm{g} / \mathrm{kg}$ and/or dexamethasone (Dex) $5 \mathrm{mg} / \mathrm{kg} 2$ times a week followed by extraction of the first molars. Thirty percent to $33 \%$ of animals treated with $\mathrm{Zol} / \mathrm{Dex}$ and $10 \%$ treated with Zol only did not heal, resulting in exposed necrotic bone associated with histological changes typical of ONJ lesions:

Table 1. Animal studies

\begin{tabular}{|c|c|c|c|}
\hline Study & Animal & Method & Result \\
\hline Kikuiri et al. ${ }^{11}(2010)$ & Mouse & Intravenous MSCs administration & $\begin{array}{l}\text { Restored immunologic abnormalities and } \\
\text { reduced inflammatory cytokines }\end{array}$ \\
\hline Li et al. ${ }^{12}(2013)$ & Mini-pig & $\begin{array}{l}\text { Intravenous allogenic BM-MSCs } \\
\text { administration }\end{array}$ & $\begin{array}{l}\text { Restored immunologic abnormalities and } \\
\text { reduced inflammatory cytokines }\end{array}$ \\
\hline Barba-Recreo et al. ${ }^{19}$ (2015) & Mouse & Local applications of allogenic ASCs & $\begin{array}{l}\text { Reduction bone necrosis and increase of the } \\
\text { bone remodeling }\end{array}$ \\
\hline Kaibuchi et al. ${ }^{15}$ (2016) & Mouse & MSCs transplantation & Wound healing and bone neoformation \\
\hline Ogata et al. ${ }^{18}(2017)$ & Rat & $\begin{array}{l}\text { Intravenous injection of a mixture of } \\
\text { MCP-1, IGF-1 and VEGF }\end{array}$ & Wound healing and bone regeneration \\
\hline Kuroshima et al. ${ }^{20}(2018)$ & Rat & Transplantation of SVF of adipose tissue & $\begin{array}{l}\text { Reduction of bone necrosis and inflammatory } \\
\text { cytokines, increase anti-inflammatory } \\
\text { cytokines, angiogenesis and the M2/M1 ratio }\end{array}$ \\
\hline Zang et al. ${ }^{22}$ (2019) & Rabbit & Transplantation of ASCs & $\begin{array}{l}\text { Wound healing, increase expression of TGF- } \beta 1 \\
\text { and fibronectin }\end{array}$ \\
\hline Watanabe et al. ${ }^{24}(2020)$ & Mouse & EVs-MSCs & $\begin{array}{l}\text { Wound healing, bone remodeling and } \\
\text { angiogenesis }\end{array}$ \\
\hline Gao et al. $^{23}(2021)$ & Rat & $\begin{array}{l}\text { Local administration of recombinant } \\
\text { PDGF-BB }\end{array}$ & Angiogenesis and osteogenesis \\
\hline
\end{tabular}

(MSCs: mesenchymal stem cells, BM-MSC: bone marrow MSCs, MCP-1: monocyte chemoattractant protein-1, IGF-1: insulin-like growth factor 1, VEGF: vascular endothelial growth factor, ASCs: adipose stem cells, SVF: stromal vascular fraction, TGF- $\beta 1$ : transforming growth factor- $\beta 1$, PDGF-BB: platelet derived growth factor BB)

Gianfilippo Nifosi et al: Mesenchymal stem cells in the treatment of osteonecrosis of the jaw. J Korean Assoc Oral Maxillofac Surg 2021 
inflammatory infiltrates, areas of bone necrosis with empty gaps, fibrosis, and missing epithelial lining. Two weeks after extraction, ONJ-mice showed reductions in Tregs lymphocytes (CD4, CD25, Foxp3) in the peripheral blood, an increase in Th17 lymphocytes and a decrease in the Tregs/ ratio Th17. Similarly, reduced interleukin (IL)-10 and increased IL- 6 and IL-17 concentrations were observed. The role of immune dysfunction has been implied by the results of treatment with anti-CD25 antibodies (CD25Ab) twice per week after tooth extraction that aggravated injuries, while the infusion of thymic lymphocytes two days after extraction prevented injuries and allowed appropriate bone regeneration with complete wound healing. Due to their immunosuppressive and immunomodulatory properties, intravenous MSCs was administered twice per week after extraction. Treatment with Tregs and MSCs made it possible to restore lymphocyte abnormalities, increase the Tregs/Th17 ratio, reduce inflammatory cytokines, and increase IL-10 levels ${ }^{11}$.

BPs induce apoptosis of MSCs and reduce their proliferative and differentiating abilities. Infusion of allogeneic bone marrow MSCs (BM-MSCs) resulted in wound healing and bone remodeling after 12 weeks with increases in peripheral levels of Tregs, while IL-17 and T $\gamma \delta$ lymphocytes decreased. After 12 months alkaline phosphatase and tartrate-resistant acid phosphatase (TRAP) expression increased, while the levels of interferon (IFN)- $\gamma$ and IL-6 decreased, indicating bone remodeling and immunoregulation ${ }^{12}$.

Studies in cardiology have shown that intravenously injected allogeneic MSCs are unstable, can have procoagulant capacity, and may lead to pulmonary embolization ${ }^{13}$, heart attacks, and death ${ }^{14}$. Therefore, researchers began to investigate direct transplantation of MSCs into bone lesions. Kaibuchi et al. ${ }^{15}$ showed that MSCs proliferative capacity, vascular endothelial growth factor (VEGF) levels, RANKL and osteo-protegerin (OPG) mRNA expression are reduced by BPs treatment in a complex mouse model. Histologically, BPs showed a lack of epithelial coating, an increase in empty osteocyte gaps, and significantly reduced average number of osteoclasts $/ \mathrm{mm}^{3}$. Two weeks after MSCs transplantation, the treated mice showed wound healing (exposed bone: 12\%) compared to control groups (exposed bone: $80 \%$ ).

The transfer of mitochondria of allogeneic MSCs to damaged MSCs is concurrent with observations in vivo, indicating a high number of $\mathrm{CD} 90^{+} \mathrm{GFP}^{-}$cells with red mitochondria located in the upper portions of the sockets ${ }^{16}$.

The paracrine secretion of human MSCs grown on serumfree culture media was demonstrated for the first time by
Ogata et al. ${ }^{17}$, who isolated 25 proteins in the cell "secretoma" with at least twice the concentration of controls and with at least 10 proteins involved in tissue regeneration, osteogenesis, angiogenesis, and cell proliferation. By inhibiting osteoclastogenesis with anti-RANKL antibodies, they demonstrated that the addition of MSCs recovered this capacity, as demonstrated by the increase in TRAP+cells and mRNA levels of the Nfatc1 and c-Fos genes whose proteins were upregulated. The most representative cytokines of the secretoma were the chemoattractant proteins of monocytes (MCP-1), insulin-like growth factor (IGF-1), and VEGF. A mixture of these three cytokines injected intravenously allowed wound healing and bone regeneration in $67 \%$ of animals ${ }^{18}$.

In recent years, the attention of researchers has shifted to stem cells derived from adipose stem cells (ASCs). BarbaRecreo et al. ${ }^{19}$ first used local applications of 1 million allogeneic ASCs in a mouse model, with or without previous stimulation with bone morphogenetic protein-2 (BMP-2) and/ or platelet rich plasma (PRP). Alveolar bone necrosis was present in $50 \%$ of untreated animals and only in $14 \%$ of those treated $(P=0.007)$. There were also significant differences in the number of osteoclasts observed $(P=0.0045)$ and in bone remodeling $(P=0.024)$.

The use of stromal vascular fraction (SVF) obtained from adipose tissue to cure of ONJ lesions induced by an association of zoledronate $(0.05 \mathrm{mg} / \mathrm{kg}$ subcutaneously) and cyclophosphamide (150 mg/kg intraperitoneally) resulted in fewer mucosal lesions, bone necroses, and empty bone gaps, and greater numbers of osteoclasts, vital bone areas, and osteocytes ${ }^{20}$. In connective tissue, the number of TRAP + mononuclear cells and detached osteoclasts was reduced, tumor necrosis factor $\alpha$ (TNF- $\alpha$ ) levels were reduced, and IL-1 $\beta$ levels were increased. Similarly, the number of blood vessels, total vascular surface, and number of wide vessels increased. Finally, the number of F4/80+macrophages and the $\mathrm{M} 2 / \mathrm{M} 1$ ratio were both greater.

These results were confirmed more recently in a mouse model, demonstrating higher bone neoformation $(P=0.044)$ and greater vascularization (not statistically significant) in animals treated with ASCs. Instead, no differences were observed in the number of osteoclasts, inflammatory infiltrates, or bone remodeling ${ }^{21}$.

Down-regulation of transforming growth factor (TGF- $\beta 1$ ) and fibronectin has been demonstrated in induced ONJ lesions, and transplanted ASCs have been observed to increase their expression, preventing and accelerating wound healing ${ }^{22}$.

The reduced osteogenic and angiogenic function of man- 
dibular medullary MSCs can be countered by the local administration of recombinant platelet derived growth factor BB (PDGF-BB), which was able to improve lesions through increases of angiogenesis and osteogenesis ${ }^{23}$.

In a study that appeared earlier in the year (2020), Watanabe et al. ${ }^{24}$ reported that extracellular vesicles (EVs) released by MSCs are also capable of inducing wound healing, bone remodeling, and angiogenesis in a mouse model of MRONJ. The addition of EVs to a culture of bone marrow stem cells (BMSCs) in vitro treated with Zol reduced the number of beta-galactosidase+cells and the expressions of p21 and $\mathrm{pRB}$ typical of cell senescence, while in vivo it increased the gene expressions of Bmil and Hmga2 typical of stem cells. The path of cell-free regenerative therapy in the treatment of MRONJ is therefore mapped out.

\section{Clinical applications in humans}

The results of studies in humans are summarized in Table 2. The first use of MSCs to treat MRONJ dates back to Elad et al. ${ }^{25}$ in 2005 , in which a suspension of $2.7 \times 10^{6}$ allogeneic MSCc was applied to the margins of exposed bone in a 55-year-old patient with multiple myeloma who had been treated with nitro-BPs for 6 years. The authors reported a marked reduction in the size of the exposed alveolar bone and complete healing in five months, which was maintained up to seven years after treatment ${ }^{25}$.

Previously, Matsubara et al. ${ }^{26}$ studied the alveolar spinal stem cells (BMSCs) of patients undergoing oral surgery, and reported that these cells had good ability to expand in culture independent of sex, but that this ability decreases with age and shows impairment after 50 years. They have excellent osteogenic ability, but worse chondrogenic and adipogenic abilities, when compared with iliac crest derived $\mathrm{MSCs}^{26}$.

Cella et al. ${ }^{27}$ reported a 75 -year-old woman with stage III MRONJ who was treated with a stem cell suspension that was obtained by taking $75 \mathrm{~mL}$ of bone marrow from the postero-superior iliac crest. The progenitor cells were isolated and enriched by centrifugation in Ficoll-Hypaque and suspended in phosphate-buffered saline buffered with EDTA with 5\% human albumin. The stem cell fraction was concentrated in a final volume of $6 \mathrm{~mL}$, of which $4 \mathrm{~mL}$ was associated with $1 \mathrm{~mL}$ of PRP and transplanted intralesionally using a fibrin sponge as a carrier. After 2 weeks the patient's symptoms resolved and the mucosal lining progressively improved. After 15 months computed tomography showed concentric bone neoformation, and finally after 30 months, complete resolution of the ONJ lesions was observed.

BM-MSCs of the central and peripheral areas of MRONJ patients show lower proliferative capacity and self-renewal ability, especially in the center and less so in peripheral wound areas. Osteogenic and adipogenic capacity are compromised in the central area compared to the peripheral area. Finally, the ability to induce osteoclastic differentiation expressed by the RANKL entity is greatly impaired in the central areas $^{28}$.

Six osteoporotic patients with an average age of 65.2 years (range, 57-77 years) with stage I (one case) and II (five patients) MRONJ were treated using autologous concentrates of BM-MSCs transplanted after necrotic bone removal in the

Table 2. Clinical applications

\begin{tabular}{|c|c|c|c|}
\hline Study & Case & Method & Result \\
\hline Elad et al. ${ }^{25}(2005)$ & MRONJ in multiple myeloma & $\begin{array}{l}\text { Application of allogeneic MSCs on the } \\
\text { margins of the exposed bone }\end{array}$ & $\begin{array}{l}\text { Complete healing in five months } \\
\text { maintained up to seven years after } \\
\text { treatment }\end{array}$ \\
\hline Cella et al. ${ }^{27}(2011)$ & Stage III MRONJ & $\begin{array}{l}\text { Intralesional transplanted allo-MSCs } \\
\text { with fibrin sponge }\end{array}$ & Complete resolution in 30 months \\
\hline Voss et al. $^{29}$ (2017) & $\begin{array}{l}\text { Stage I MRONJ (one case) and } \\
\text { II (five cases) }\end{array}$ & $\begin{array}{l}\text { Autologous BM-MSCs concentrates in } \\
\text { the BMAC system }\end{array}$ & $\begin{array}{l}\text { Complete wound healing confirmed by } \\
\text { radiological examination at a follow-up } \\
\text { of } 12-54 \text { months }\end{array}$ \\
\hline De Santis et al. ${ }^{30}(2020)$ & $\begin{array}{l}\text { MRONJ in multiple myeloma } \\
\text { and metastatic breast cancer }\end{array}$ & $\begin{array}{l}\text { Bone implant (Geistlich Bio-Oss) and } \\
\text { MSCs transplanted to the peripheral } \\
\text { areas; injection of MSCs directly into } \\
\text { the bone cavity }\end{array}$ & $\begin{array}{l}\text { Improvement and complete radiological } \\
\text { bone regeneration } 14 \text { months and } 12 \\
\text { months respectively }\end{array}$ \\
\hline Bouland et al. ${ }^{31}$ (2020) & $\begin{array}{l}\text { Two cases of MRONJ by } \\
\text { Zoledronic acid }\end{array}$ & $\begin{array}{l}\text { Application of the leukocyte- } \\
\text { platelet-rich fibrin (L-PRF) scaffold } \\
\text { containing SVF }\end{array}$ & $\begin{array}{l}\text { Mucosal healing two weeks after the } \\
\text { procedure; bone formation; no signs of } \\
\text { clinical recurrence during the 18-month } \\
\text { follow-up. }\end{array}$ \\
\hline
\end{tabular}

(MRONJ: medication-related osteonecrosis of the jaw, MSCs: mesenchymal stem cells, BM-MSCs: bone marrow MSCs, BMAC: bone marrow aspirated concentrate, SVF: stromal vascular fraction)

Gianfilippo Nifosi et al: Mesenchymal stem cells in the treatment of osteonecrosis of the jaw. J Korean Assoc Oral Maxillofac Surg 2021 
bone marrow aspirated concentrate (BMAC) system, with the addition of autologous thrombin and a collagen membrane. In all patients, complete wound healing was achieved without exposed bone or fistulae, and confirmed by radiological examination at a follow-up of 12 to 54 months ${ }^{29}$.

Recently, De Santis et al. ${ }^{30}$ presented two clinical cases in a letter to the editor. The first was a 68 -year-old man with multiple myeloma and MRONJ treated with a bone implant (Geistlich Bio-Oss) inside which $0.6 \times 10^{6}$ MSCs were injected, while later $30 \times 10^{6} \mathrm{MSC}$ were transplanted to the peripheral areas. The second was a 66-year-old woman with metastatic breast cancer and MRONJ treated with an injection of $110 \times 10^{6}$ MSCs directly into the bone cavity. In both cases, clinical improvement and complete radiological bone regeneration were obtained in 14 months and 12 months, respectively.

Finally, Bouland et al. ${ }^{31}$ reported two cases of MRONJ caused by zoledronic acid that were treated with applications of a leukocyte-platelet-rich fibrin (L-PRF) scaffold containing uncultured SVF and site closure with a mucoperiosteal flap. In the first case, a 77-year-old woman with multiple myeloma in remission and stage III MRONJ, a total of $48.1 \times 10^{6}$ viable cells were injected in the L-PRF scaffold. In the second case, a 76-year-old woman with osteoporosis and stage II MRONJ that began after removal of one tooth, a total of $20.8 \times 10^{6}$ viable cells were injected in the L-PRF scaffold. In both cases, mucosal healing was achieved two weeks after the procedure, bone formation with osteocondensation was documented by three consecutive cone beam computed tomography studies, bony bridges were observed 18 months after intervention, and no signs of clinical recurrence were seen during 18 months of follow-up.

\section{Discussion}

\section{Characteristics of MSCs}

MSCs were originally isolated from bone marrow (BMMSCs), where they represent a multipotent non-hematopoietic cell line of the medullary stroma $(0.001 \%-0.01 \%$ of total nucleated cells) that is ten times less abundant than hematopoietic stem cells ${ }^{32}$. They were later identified in many other tissues including adipose tissue ${ }^{33}$, connective tissue, dental pulp and periodontal ligament, skin, placenta, amniotic fluid, fetal tissues, and umbilical cord blood ${ }^{34}$. Recently, they have also been isolated from the peripheral blood (PB-MSCs) of many animals, at low concentrations and with some pheno- typic (high expression of CD146) and probably kinetic (low proliferative capacity) differences ${ }^{35}$. The International Society for Cellular Therapy (ISCT) has defined minimum criteria to define $\mathrm{MSCs}^{36}$ :

a) adherence to plastic under standard culture conditions;

b) typical immunophenotype: $>95 \%$ positivity to CD105, CD73, and CD90 and negativity to CD34, CD45, CD14 or CD11b, CD79a or CD19, HLA-DR; and

c) ability to differentiate in vitro towards osteoblasts, chondroblasts and adipocytes.

MSCs express phenotypic markers ${ }^{37}$ that are used to identify them: CD106 (VCAM1), CD 105 (SH2 or endoglin), CD 73 (SH3 or SH4), CD90 (Thy-1), CD166 (leukocyte adhesion molecule), CD44 (hyaluronic acid receptor), CD29 (subunit of the integrin $\beta 1$ ), and CD13 (aminopeptidase N). Some adipose tissue-derived MSCs (ASCs) expresses CD34 ${ }^{38}$ and these CD34+ASCs pericytes-like interact with endothelial cells ${ }^{39}$.

Numbers of BM-MSCs decrease with age, as do their osteogenic proliferative and differentiating capacity, probably due to lost superoxide dismutase that makes them more sensitive to oxidative stress ${ }^{40}$. These cells can be expanded widely in culture in the presence of autologous serum or human platelet lysate.

The first ability of MSCs is self-renewal ${ }^{41}$. The second is responsiveness to biological signals of inflammation, necrosis, and cell damage, which induce them to migrate to damaged tissues and facilitate tissue repair. This ability is due to their great differentiation plasticity. Classically, they have been described as cells capable of differentiating into mesenchymal cell lines, in particular bone, cartilage, and adipose tissues. Differentiation into osteocytes is possible by growing MSCs in the presence of dexamethasone, ascorbic acid, and beta-glycerophosphate.

MSCs have immunoregulatory properties that have been demonstrated both in vitro and in vivo, in animal models ${ }^{42}$ and in humans ${ }^{43}$. They have always been considered immune privilege cells due to the low levels of expression of MHCI antigens and the lack of expression of MHC-II and costimulatory molecules. Eliopoulos et al. ${ }^{44}$ have shown that allogeneic MSCs are rejected by immunocompetent recipients, especially when they are induced to differentiate into cells of the osteocyte line.

ASCs have higher immunomodulatory activity, greater proliferation capacity, and exhibit less senescence when expanded ex vivo ${ }^{45}$. Osteogenic differentiation would be lower, while they would have greater angiogenic activity through the pro- 
duction of VEGF, hepatocyte growth factor (HGF), and betabeta-fibroblast growth factor (FGF). Finally, the production of macrophage colony-stimulating factor (M-CSF), RANKL, BMP-2 and 4, and HGF explain their intervention in bone remodeling ${ }^{45}$. Recently, pre-conditioning in culture with desferroxamine, simulating a hypoxic condition, has been shown to increase hypoxia-inducible factor (HIF $1 \alpha$ ) production, which acts on intracellular pathways to increase the production of angiogenic, anti-inflammatory, neuro-protective, and antioxidant factors involved in wound healing, neo-vascularization, and restoration of normal epithelial thickness ${ }^{46}$. A key role is expected to be played by the production of TGF- $\beta 1$, which is reduced by BPs treatment, because it increases the expression of fibronectin, the synthesis of which depends on the cJun pathway ${ }^{47}$. Fibronectin can induce epithelial regeneration by activating precursor cells through the recognition of the tripeptide Arg-Gly-Asp (RGD) sequence of the $\alpha 5 \beta 1$ integrin receptor $^{48}$. Furthermore, TGF- $\beta 1$ stimulates migration and proliferation of fibroblasts, synthesis of extra-cellular matrix, and production of fibronectin ${ }^{49}$. In this way, ASCs would promote early healing of gingival lesions, which would reduce the infiltration of inflammatory cells into the sub-gingival connective tissue, avoiding exposure of the exposed bone to bacteria in the oral cavity and creating an optimal microenvironment for bone neoformation ${ }^{22}$.

The SVF, which can be easily obtained from adipose tissue by liposuction and isolated by enzymatic treatment and centrifugation, contains a heterogeneous population of hematopoietic (CD45+), endothelial (CD31+), and stromal cells (CD34+). The healing of soft tissue injuries would be favored by increases in cell proliferation and angiogenesis, reduction of inflammation, and increase of fibroblastic activity ${ }^{50}$. Finally, bone remodeling would be favored through the reduction of TRAP + mononuclear cells and detached osteoclasts, which are increased in bone lesions induced by combined chemotherapy/BP. Bone neo-formation is significantly greater in MSC and endothelial precursor cell (EPC) co-culture compared to MSC-only culture ${ }^{51}$. EPC would not have a role in osteogenic differentiation, but rather influence osteoblastogenesis through angiogenesis, and plays a dynamic role in maintaining MSC stemness and pluripotency capacities ${ }^{52}$. SVF strongly facilitates blood vessel formation ${ }^{53}$ and vascularization, which play key roles in bone regeneration.

MSCs have demonstrated key therapeutic roles in various diseases by producing a wide spectrum of autocrine and paracrine factors (secretome). Several studies have demonstrated the predominance of short-lived paracrine mechanisms among the therapeutic actions of $\mathrm{MSCs}^{54}$. Characterization of the secretome can help explain their mechanisms of action. In particular, the metabolomic analysis of EVs derived from MSCs would explain their ability to mediate tissue repair and cell regeneration. It is interesting to consider the possibility that exogenously administered MSCs can communicate with endogenous MSCs and other cells by transferring information and regulatory genes mediated, to some extent, by released EVs. Therefore, EVs derived from MSCs cultures have the potential to constitute safe and effective therapy without cells $^{55}$. The International Society for Extracellular Vesicles has suggested using the term EVs preferentially to describe preparations of vesicles from body fluids and cell cultures. Three types of EVs are distinguished based on their diameters: exosomes (30-100 nm), micro-vesicles (50-1,000 nm), and apoptotic bodies $(1,000-5,000 \mathrm{~nm})^{56}$. It has been known for some time that MSCs release different EVs depending on external stimulation, suggesting that this process is regulated by the cross-talk between MSCs and the surrounding microenvironment ${ }^{57}$. Therefore, EVs represent the means of intercellular communication through the transfer of important biomolecules, proteins, mRNA, and miRNA ${ }^{58}$. They have been shown to induce anti-inflammatory cytokines and trigger apoptosis in activated $\mathrm{T}$ cells and to carry mRNA-encoding immunoregulatory mediators, such as cytokine receptorlike factor 1 , IL-1 receptor, and metallothionein $1 \mathrm{X}^{59}$. The mitochondria transfer with mi-RNA from transplanted MSCs to endogenous MSCs represents another potential mechanism by which these cells can reconvert damaged endogenous cells and stimulate them to initiate self-renewal and cell differentiation $^{60}$.

\section{Use of MSCs in MRONJ}

Some preclinical studies and clinical trials have confirmed the potential of MSCs for treating several diseases, with the aim of repairing or replacing cells, tissues, or organs damaged by age, disease, or trauma, as well as to address congenital defects. In multiple MRONJs, the classical treatment is sometimes insufficient and cell therapy and tissue engineering are a potential therapeutic option. The osteogenic plasticity of MSCs is interesting in this setting. The therapeutic role of MSCs in MRONJ would be facilitated by:

- immunomodulatory and anti-inflammatory capacity, through the downregulation of TH17 and $\gamma \delta \mathrm{T}$ cells, consequently reducing IL-17, IL-1 $\beta$, IL-6, C-reactive protein, TNF- $\alpha$, and IFN- $\gamma$ levels, and the upregulation of Tregs 
with increases of IL-10 and TGF- $\beta$ levels ${ }^{61}$;

- stimulation of angiogenesis through the production of growth factors $\left(\mathrm{VEGF}^{62}\right.$ and HIF1- $\alpha^{63}$ ), chemokines, and exosomes, direct differentiation into endothelial cells, and new vessel stabilization through localization in perivascular positions as pericytes CD146 $+{ }^{64}$;

- antibacterial activity through increase of bacterial killing by immune cells ${ }^{65}$ and production of anti-bacterial peptides, such as LL-37çç ${ }^{66}$;

- stimulation of gingival wound healing through paracrine factors (TGF- $\beta 1$ ) secretion and increase in cellular survival, proliferation, migration, and differentiation ${ }^{67}$; and

- differentiation of precursors to osteoclasts through RANKL production, thus accelerating bone turnover ${ }^{45}$.

In pre-clinical studies, MSCs have been administered intravenously, intra-arterially, and intra-peritoneally. In humans, intravenous infusion has also been used in many contexts, such as the control of refractory acute grafts versus host disease (GVHD) to the acceleration of hematological recovery after hematopoietic stem cell transplantation ${ }^{68}$, autoimmune diseases such as inflammatory bowel disease $\mathrm{e}^{69,70}$, osteogenesis imperfecta $^{71}$, metabolic diseases, and autism ${ }^{72}$. In the context of MRONJ, and more generally in the context of cell therapy in regenerative medicine, autologous MSCs are administered as intralesional, percutaneous, or surgical transplants, i.e., through the direct injection of a cell suspension as such or expanded ex vivo, isolated, or complexed with a three-dimensional scaffold in the area of bone lesions. For small bone lesions, the use of collagen or fibrin sponges or autologous thrombin is also feasible ${ }^{73}$. Moreover, fibrin matrix appears to be a relevant scaffold to support osteoblastic growth and differentiation. PRF is a second-generation platelet concentrate and can be distinguished as pure PRF (P-PRF) or L-PRF ${ }^{74}$. L-PRF is an autologous three-dimensional fibrin scaffold obtained by whole blood centrifugation without the addition of any other component. Factors freed by platelets contained in L-PRF induce and control the proliferation and migration of other cell types involved in tissue repair, like $\mathrm{MSCs}^{75}$. In particular, platelet-derived growth factors (VEGF, epidermal growth factor [EGF], BMP-2, TGF- $\beta 1$, and PDGF), when released for at least seven days, stimulate the regenerative and healing potential of soft and hard tissues locally and can play a role in antibacterial activity through antimicrobial protein release $^{76}$. Among the most used three-dimensional scaffolds in the dental field is ceramic, usually hydroxyapatite and tricalcium phosphate, which is well suited to bone neoformation. The main problem associated with such treatment is bad resorption, for which other inert biodegradable biomaterials have been developed including polymers such as poly (lacticco-glycolic acid) and poly ( $\varepsilon$-caprolactone $)^{77}$. These biomaterials promote the adhesion, proliferation, and osteoblastic differentiation of MSCs, as well as the production and subsequent mineralization of the extracellular matrix ${ }^{78}$. It remains to be clarified which materials are most suitable to support bone-medullary differentiation action and to guide the neovascularization of lesions.

\section{Advantages}

Autologous BM-MSCs administration are an option for conventional treatment-refractory MRONJ. Their osteogenic potential has long been demonstrated. Their high immunomodulatory properties play roles in bone formation in sites under reconstruction by reducing inflammation and other local factors that may oppose endogenous bone regeneration. PB-MSCs have been identified that make bone in vivo, but they are extremely scarce ${ }^{79}$. The induced pluripotent stem cells (iPSCs) arise from adult somatic cells that are genetically reprogrammed to an embryonic stem cell-like state. They have extensive proliferation capacity and can be coerced into osteoblastic differentiation to produce large numbers of cells $^{80}$. Adipose tissue represents a privileged source of MSCs due to its accessibility and the high MSC content in these cells. ASCs are characterized by faster cell proliferation, stable population doubling, and lower levels of senescence than BM-MSCs. They have less osteogenic capacity, but greater angiogenic and anti-inflammatory activity ${ }^{81}$, and are capable of secreting a great variety of growth factors with significant impacts on tissue regeneration ${ }^{82}$. Their combination with platelet-rich plasma (PRP) is synergic ${ }^{19}$. The SVF of adipose tissue can be obtained through simple and safe procedures and treatment times (1 hour) are reduced without the need for cell cultures. SVF showed greater bone formation, probably due to synergy between the different cell populations, particularly EPCs, and higher neo-vascularization that drives bone formation. EVs-MSCs isolation is sustainable and reproducible. Due to their lipidic structure they are easily stored for long periods at $-80^{\circ} \mathrm{C}$ and can cross the blood brain barrier ${ }^{83}$. They can be immobilized on a variety of polymer-based scaffolds, such as fibronectin ${ }^{84}$, poly lactic-co-glycolic acid ${ }^{85}$, and hydrogel sponge ${ }^{86}$. In some cases, the protective effects of EVs are significantly better than those of $\mathrm{MSCs}^{87}$. In addition, they offer specific benefits for patient safety, such as low propensity to trigger innate and adaptive immune responses 
and the inability to directly give rise to tumors ${ }^{88}$.

\section{Disadvantages}

Genetic instability of iPSCs could lead to tumor formation in the host tissue, a possibility that should be evaluated ${ }^{89,90}$. The number of BM-MSCs that can be obtained by a single procedure is limited, and bone marrow biopsy is an invasive procedure that requires general anesthesia. Moreover, the number of iPSCs decreases with age. Intravenous injection of MSCs determines the capture of the majority of cells into capillary beds, especially in the lungs, but also in spleen, liver, and kidney. This systemic clearance means that only a small number of MSCs reach the target site. Moreover, such treatment poses the risk of pulmonary thromboembolism due to aggregation in the pulmonary circulation ${ }^{91,92}$ and can trigger disseminated intravascular coagulation due to procoagulant activity ${ }^{93}$. As a result of immunosuppression, there is greater risk of the onset of tumors or the progression of existing malignancies ${ }^{90}$ and genetic instability of expanded cells in vitro ${ }^{94}$. The bone marrow, a potential source for cell therapy, is invaded by medullary clonal plasma cells in multiple myeloma. The interactions between malignant cells and the BM microenvironment contributes to abnormalities in BM-MSC, such as IL-6 and DKK1 overexpression and early senescence $^{95}$. For this reason, autologous BM-MSCs cannot be used for MRONJ treatment in multiple myeloma patients. Conversely, ASC and SVF present no abnormalities and can be used as an alternative source for this setting. Another important safety aspect is the possibility of ectopic calcifications, as observed at the coronary level in animals subjected to local infusion ${ }^{14}$.

The immunogenicity of these cells is low. If they can take root in immunocompromised hosts or in immune privileged sites, they can elicit immune responses in hosts with an intact immune systems, being able to act as APCs under certain conditions, for example when stimulated by IFN- $\gamma^{96}$. Finally, the use of EVs also poses problems, as their half-life is not clear (affecting effect duration) and the long culture times necessary to obtain sufficient material for clinical use.

\section{Future research}

Further studies are needed to clarify the most appropriate cellular sources and ideal number of cells to be transplanted, as well as the times and the best method of administration, for treatment of MRONJs by EVs. Certainly, the osteogenic plasticity and immunomodulatory properties of these cells is interesting, and in the not too distant future they will offer new therapeutic opportunities in the field of oral, maxillofacial, and implantology surgery, thanks to totally cellularfree cell therapy. EVs are excellent potential candidates for therapeutic targets to treat MRONJ. We recommend the use of randomized controlled trials to evaluate the efficacy and safety of these new treatments.

\section{ORCID}

Gianfilippo Nifosì, https://orcid.org/0000-0003-4329-6297

Lorenzo Nifosì, https://orcid.org/0000-0002-9175-6975

Antonio Fabrizio Nifosì, https://orcid.org/0000-0001-75967767

\section{Authors' Contributions}

G.N. participated in the study design and performed the statistial analysis. A.F.N. participated in data collection and wrote the manuscript. L.N. participated in the study design and coordination and helped to draft the manuscript. All authors read and approved the final manuscript.

\section{Conflict of Interest}

No potential conflict of interest relevant to this article was reported.

\section{References}

1. Marx RE. Pamidronate (Aredia) and zoledronate (Zometa) induced avascular necrosis of the jaws: a growing epidemic. J Oral Maxillofac Surg 2003;61:1115-7. https://doi.org/10.1016/s02782391(03)00720-1

2. Ruggiero SL, Dodson TB, Fantasia J, Goodday R, Aghaloo T, Mehrotra B, et al.; American Association of Oral and Maxillofacial Surgeons. American Association of Oral and Maxillofacial Surgeons position paper on medication-related osteonecrosis of the jaw--2014 update. J Oral Maxillofac Surg 2014;72:1938-56. https://doi.org/10.1016/j.joms.2014.04.031

3. Rollason V, Laverrière A, MacDonald LC, Walsh T, Tramèr MR, Vogt-Ferrier NB. Interventions for treating bisphosphonate-related osteonecrosis of the jaw (BRONJ). Cochrane Database Syst Rev 2016;2:CD008455. https://doi.org/10.1002/14651858.CD008455. pub2

4. Lombard T, Neirinckx V, Rogister B, Gilon Y, Wislet S. Medication-related osteonecrosis of the jaw: new insights into molecular mechanisms and cellular therapeutic approaches. Stem Cells Int 2016;2016:8768162. https://doi.org/10.1155/2016/8768162

5. Fortunato L, Bennardo F, Buffone C, Giudice A. Is the application of platelet concentrates effective in the prevention and treatment of medication-related osteonecrosis of the jaw? A systematic review. 
J Craniomaxillofac Surg 2020;48:268-85. https://doi.org/10.1016/ j.jcms.2020.01.014

6. Bernardo ME, Locatelli F, Fibbe WE. Mesenchymal stromal cells. Ann N Y Acad Sci 2009;1176:101-17. https://doi.org/10.1111/ j.1749-6632.2009.04607.x

7. Nauta AJ, Fibbe WE. Immunomodulatory properties of mesenchymal stromal cells. Blood 2007;110:3499-506. https://doi. org/10.1182/blood-2007-02-069716

8. Gangji V, Hauzeur JP. Cellular-based therapy for osteonecrosis. Orthop Clin North Am 2009;40:213-21. https://doi.org/10.1016/ j.ocl.2008.10.009

9. Quarto R, Mastrogiacomo M, Cancedda R, Kutepov SM, Mukhachev V, Lavroukov A, et al. Repair of large bone defects with the use of autologous bone marrow stromal cells. N Engl J Med 2001;344:385-6. https://doi.org/10.1056/NEJM200102013440516

10. Gangji V, Hauzeur JP, Matos C, De Maertelaer V, Toungouz M, Lambermont M. Treatment of osteonecrosis of the femoral head with implantation of autologous bone-marrow cells. A pilot study. J Bone Joint Surg Am 2004;86:1153-60. https://doi. org/10.2106/00004623-200406000-00006

11. Kikuiri T, Kim I, Yamaza T, Akiyama K, Zhang Q, Li Y, et al. Cellbased immunotherapy with mesenchymal stem cells cures bisphosphonate-related osteonecrosis of the jaw-like disease in mice. J Bone Miner Res 2010;25:1668-79. https://doi.org/10.1002/jbmr.37

12. Li Y, Xu J, Mao L, Liu Y, Gao R, Zheng Z, et al. Allogeneic mesenchymal stem cell therapy for bisphosphonate-related jaw osteonecrosis in Swine. Stem Cells Dev 2013;22:2047-56. https://doi. org $/ 10.1089 / \mathrm{scd} .2012 .0615$

13. Tatsumi K, Ohashi K, Matsubara Y, Kohori A, Ohno T, Kakidachi $\mathrm{H}$, et al. Tissue factor triggers procoagulation in transplanted mesenchymal stem cells leading to thromboembolism. Biochem Biophys Res Commun 2013;431:203-9. https://doi.org/10.1016/ j.bbrc.2012.12.134

14. Breitbach M, Bostani T, Roell W, Xia Y, Dewald O, Nygren JM, et al. Potential risks of bone marrow cell transplantation into infarcted hearts. Blood 2007;110:1362-9. https://doi.org/10.1182/ blood-2006-12-063412

15. Kaibuchi N, Iwata T, Yamato M, Okano T, Ando T. Multipotent mesenchymal stromal cell sheet therapy for bisphosphonaterelated osteonecrosis of the jaw in a rat model. Acta Biomater 2016;42:400-10. https://doi.org/10.1016/j.actbio.2016.06.022

16. Matsuura Y, Atsuta I, Ayukawa Y, Yamaza T, Kondo R, Takahashi A, et al. Therapeutic interactions between mesenchymal stem cells for healing medication-related osteonecrosis of the jaw. Stem Cell Res Ther 2016;7:119. https://doi.org/10.1186/s13287-016-0367-3

17. Ogata K, Katagiri W, Hibi H. Secretomes from mesenchymal stem cells participate in the regulation of osteoclastogenesis in vitro. Clin Oral Investig 2017;21:1979-88. https://doi.org/10.1007/ s00784-016-1986-x

18. Ogata K, Matsumura M, Moriyama M, Katagiri W, Hibi H, Nakamura S. Cytokine mixtures mimicking secretomes from mesenchymal stem cells improve medication-related osteonecrosis of the jaw in a rat model. JBMR Plus 2017;2:69-80. https://doi.org/10.1002/ jbm4.10013

19. Barba-Recreo P, Del Castillo Pardo de Vera JL, Georgiev-Hristov T, Ruiz Bravo-Burguillos E, Abarrategi A, Burgueño M, et al. Adipose-derived stem cells and platelet-rich plasma for preventive treatment of bisphosphonate-related osteonecrosis of the jaw in a murine model. J Craniomaxillofac Surg 2015;43:1161-8. https:// doi.org/10.1016/j.jcms.2015.04.026

20. Kuroshima S, Sasaki M, Nakajima K, Tamaki S, Hayano H, Sawase $\mathrm{T}$. Transplantation of noncultured stromal vascular fraction cells of adipose tissue ameliorates osteonecrosis of the jaw-like lesions in mice. J Bone Miner Res 2018;33:154-66. https://doi. org/10.1002/jbmr.3292

21. Alonso-Rodriguez E, González-Martín-Moro J, Cebrián-Carretero JL, Del Castillo JL, Pozo-Kreilinger JJ, Ruiz-Bravo E, et al.
Bisphosphonate-related osteonecrosis. Application of adiposederived stem cells in an experimental murine model. Med Oral Patol Oral Cir Bucal 2019;24:e529-36. https://doi.org/10.4317/ medoral.22959

22. Zang X, He L, Zhao L, He Y, Xiao E, Zhang Y. Adipose-derived stem cells prevent the onset of bisphosphonate-related osteonecrosis of the jaw through transforming growth factor $\beta$-1-mediated gingival wound healing. Stem Cell Res Ther 2019;10:169. https:// doi.org/10.1186/s13287-019-1277-y

23. Gao SY, Lin RB, Huang SH, Liang YJ, Li X, Zhang SE, et al. PDGF-BB exhibited therapeutic effects on rat model of bisphosphonate-related osteonecrosis of the jaw by enhancing angiogenesis and osteogenesis. Bone 2021;144:115117. https://doi.org/10.1016/ j.bone.2019.115117

24. Watanabe J, Sakai K, Urata Y, Toyama N, Nakamichi E, Hibi H. Extracellular vesicles of stem cells to prevent BRONJ. J Dent Res 2020;99:552-60. https://doi.org/10.1177/0022034520906793

25. Elad S, Czerninski R, Avgil M, Or R. Hematopoietic stem cells and bisphosphonate-related osteonecrosis of the jaw. Support Care Cancer 2005;13:455. https://doi.org/10.1111/odi.12056

26. Matsubara T, Suardita K, Ishii M, Sugiyama M, Igarashi A, Oda R, et al. Alveolar bone marrow as a cell source for regenerative medicine: differences between alveolar and iliac bone marrow stromal cells. J Bone Miner Res 2005;20:399-409. https://doi.org/10.1359/ JBMR.041117

27. Cella L, Oppici A, Arbasi M, Moretto M, Piepoli M, Vallisa D, et al. Autologous bone marrow stem cell intralesional transplantation repairing bisphosphonate related osteonecrosis of the jaw. Head Face Med 2011;7:16. https://doi.org/10.1186/1746-160X-7-16

28. He LH, Xiao E, An JG, He Y, Chen S, Zhao L, et al. Role of bone marrow stromal cells in impaired bone repair from BRONJ osseous lesions. J Dent Res 2017;96:539-46. https://doi. org $/ 10.1177 / 0022034517691507$

29. Voss PJ, Matsumoto A, Alvarado E, Schmelzeisen R, Duttenhöfer F, Poxleitner P. Treatment of stage II medication-related osteonecrosis of the jaw with necrosectomy and autologous bone marrow mesenchymal stem cells. Odontology 2017;105:484-93. https://doi. org/10.1007/s10266-017-0295-4

30. De Santis GC, de Macedo LD, Orellana MD, Innocentini LMAR, Ferrari TC, Ricz HMA, et al. Mesenchymal stromal cells administration for osteonecrosis of the jaw caused by bisphosphonate: report of two cases. Acta Oncol 2020;59:789-92. https://doi.org/10. 1080/0284186X.2020.1730004

31. Bouland C, Meuleman N, Widelec J, Keiani-Mothlagh K, Voisin C, Lagneaux L, et al. Case reports of medication-related osteonecrosis of the jaw (MRONJ) treated with uncultured stromal vascular fraction and L-PRF. J Stomatol Oral Maxillofac Surg 2020. https://doi. org/10.1016/j.jormas.2020.05.024 [Epub ahead of print]

32. Caplan AI, Bruder SP. Mesenchymal stem cells: building blocks for molecular medicine in the 21 st century. Trends Mol Med 2001;7:259-64. https://doi.org/10.1016/s1471-4914(01)02016-0

33. Zuk PA, Zhu M, Mizuno H, Huang J, Futrell JW, Katz AJ, et al. Multilineage cells from human adipose tissue: implications for cell-based therapies. Tissue Eng 2001;7:211-28. https://doi. org/10.1089/107632701300062859

34. Robey PG. Cell sources for bone regeneration: the good, the bad, and the ugly (but promising). Tissue Eng Part B Rev 2011;17:42330. https://doi.org/10.1089/ten.teb.2011.0199

35. Lotfy A, El-Sherbiny YM, Cuthbert R, Jones E, Badawy A. Comparative study of biological characteristics of mesenchymal stem cells isolated from mouse bone marrow and peripheral blood. Biomed Rep 2019;11:165-70. https://doi.org/10.3892/br.2019.1236

36. Dominici M, Le Blanc K, Mueller I, Slaper-Cortenbach I, Marini F, Krause D, et al. Minimal criteria for defining multipotent mesenchymal stromal cells. The International Society for Cellular Therapy position statement. Cytotherapy 2006;8:315-7. https://doi. org/10.1080/14653240600855905 
37. Buhring HJ, Battula VL, Treml S, Kanz L, Vogel W. Novel markers for the isolation of primary bone marrow derived MSC with multilineage differentiation capacity. Blood 2006;108:2573. https://doi. org/10.1182/blood.V108.11.2573.2573

38. Im GI, Shin YW, Lee KB. Do adipose tissue-derived mesenchymal stem cells have the same osteogenic and chondrogenic potential as bone marrow-derived cells? Osteoarthritis Cartilage 2005;13:84553. https://doi.org/10.1016/j.joca.2005.05.005

39. Traktuev DO, Merfeld-Clauss S, Li J, Kolonin M, Arap W, Pasqualini R, et al. A population of multipotent CD34-positive adipose stromal cells share pericyte and mesenchymal surface markers, reside in a periendothelial location, and stabilize endothelial networks. Circ Res 2008;102:77-85. https://doi.org/10.1161/ CIRCRESAHA.107.159475

40. Yang YK. Aging of mesenchymal stem cells: implication in regenerative medicine. Regen Ther 2018;9:120-2. https://doi. org/10.1016/j.reth.2018.09.002

41. Kolf CM, Cho E, Tuan RS. Mesenchymal stromal cells. Biology of adult mesenchymal stem cells: regulation of niche, self-renewal and differentiation. Arthritis Res Ther 2007;9:204. https://doi. org/10.1186/ar2116

42. Djouad F, Plence P, Bony C, Tropel P, Apparailly F, Sany J, et al. Immunosuppressive effect of mesenchymal stem cells favors tumor growth in allogeneic animals. Blood 2003;102:3837-44. https://doi. org/10.1182/blood-2003-04-1193

43. Le Blanc K. Immunomodulatory effects of fetal and adult mesenchymal stem cells. Cytotherapy 2003;5:485-9. https://doi. org/10.1080/14653240310003611

44. Eliopoulos N, Stagg J, Lejeune L, Pommey S, Galipeau J. Allogeneic marrow stromal cells are immune rejected by MHC class Iand class II-mismatched recipient mice. Blood 2005;106:4057-65. https://doi.org/10.1182/blood-2005-03-1004

45. Sharaf-Eldin WE, Abu-Shahba N, Mahmoud M, El-Badri N. The modulatory effects of mesenchymal stem cells on osteoclastogenesis. Stem Cells Int 2016;2016:1908365. https://doi. org/10.1155/2016/1908365

46. Oses C, Olivares B, Ezquer M, Acosta C, Bosch P, Donoso M, et al. Preconditioning of adipose tissue-derived mesenchymal stem cells with deferoxamine increases the production of proangiogenic, neuroprotective and anti-inflammatory factors: potential application in the treatment of diabetic neuropathy. PLoS One 2017;12:e0178011. https://doi.org/10.1371/journal.pone.0178011

47. Hocevar BA, Brown TL, Howe PH. TGF-beta induces fibronectin synthesis through a c-Jun N-terminal kinase-dependent, Smad4independent pathway. EMBO J 1999;18:1345-56. https://doi. org/10.1093/emboj/18.5.1345

48. Tao T, Li Y, Gui C, Ma Y, Ge Y, Dai H, et al. Fibronectin enhances cartilage repair by activating progenitor cells through integrin $\alpha 5 \beta 1$ receptor. Tissue Eng Part A 2018;24:1112-24. https://doi. org/10.1089/ten.TEA.2017.0322

49. Clark RA, McCoy GA, Folkvord JM, McPherson JM. TGF-beta 1 stimulates cultured human fibroblasts to proliferate and produce tissue-like fibroplasia: a fibronectin matrix-dependent event. J Cell Physiol 1997;170:69-80. https://doi.org/10.1002/(SICI)10974652(199701)170:1<69::AID-JCP8>3.0.CO;2-J

50. Kaigler D, Krebsbach PH, West ER, Horger K, Huang YC, Mooney DJ. Endothelial cell modulation of bone marrow stromal cell osteogenic potential. FASEB J 2005;19:665-7. https://doi. org/10.1096/fj.04-2529fje

51. Liang Y, Wen L, Shang F, Wu J, Sui K, Ding Y. Endothelial progenitors enhanced the osteogenic capacities of mesenchymal stem cells in vitro and in a rat alveolar bone defect model. Arch Oral Biol 2016;68:123-30. https://doi.org/10.1016/j.archoralbio.2016.04.007

52. Wen L, Wang Y, Wen N, Yuan G, Wen M, Zhang L, et al. Role of endothelial progenitor cells in maintaining stemness and enhancing differentiation of mesenchymal stem cells by indirect cell-cell interaction. Stem Cells Dev 2016;25:123-38. https://doi.org/10.1089/ scd.2015.0049

53. Farré-Guasch E, Bravenboer N, Helder MN, Schulten EAJM, Ten Bruggenkate CM, Klein-Nulend J. Blood vessel formation and bone regeneration potential of the stromal vascular fraction seeded on a calcium phosphate scaffold in the human maxillary sinus floor elevation model. Materials (Basel) 2018;11:161. https://doi. org/10.3390/ma11010161

54. Marolt Presen D, Traweger A, Gimona M, Redl H. Mesenchymal stromal cell-based bone regeneration therapies: from cell transplantation and tissue engineering to therapeutic secretomes and extracellular vesicles. Front Bioeng Biotechnol 2019;7:352. https://doi. org/10.3389/fbioe.2019.00352

55. Barreca MM, Cancemi P, Geraci F. Mesenchymal and induced pluripotent stem cells-derived extracellular vesicles: the new frontier for regenerative medicine? Cells 2020;9:1163. https://doi. org/10.3390/cells 9051163

56. Lötvall J, Hill AF, Hochberg F, Buzás EI, Di Vizio D, Gardiner C, et al. Minimal experimental requirements for definition of extracellular vesicles and their functions: a position statement from the International Society for Extracellular Vesicles. J Extracell Vesicles 2014;3:26913. https://doi.org/10.3402/jev.v3.26913

57. Rani S, Ryan AE, Griffin MD, Ritter T. Mesenchymal stem cellderived extracellular vesicles: toward cell-free therapeutic applications. Mol Ther 2015;23:812-23. https://doi.org/10.1038/ mt.2015.44

58. Yáñez-Mó M, Siljander PR, Andreu Z, Zavec AB, Borràs FE, Buzas EI, et al. Biological properties of extracellular vesicles and their physiological functions. J Extracell Vesicles 2015;4:27066. https:// doi.org/10.3402/jev.v4.27066

59. Bruno S, Grange C, Deregibus MC, Calogero RA, Saviozzi S, Collino $\mathrm{F}$, et al. Mesenchymal stem cell-derived microvesicles protect against acute tubular injury. J Am Soc Nephrol 2009;20:1053-67. https://doi.org/10.1681/ASN.2008070798

60. Spees JL, Olson SD, Whitney MJ, Prockop DJ. Mitochondrial transfer between cells can rescue aerobic respiration. Proc Natl Acad Sci U S A 2006;103:1283-8. https://doi.org/10.1073/ pnas. 0510511103

61. Zhao Q, Ren H, Han Z. Mesenchymal stem cells: immunomodulatory capability and clinical potential in immune diseases. J Cell Immunother 2016;2:3-20. https://doi.org/10.1016/j.jocit.2014.12.001

62. Beckermann BM, Kallifatidis G, Groth A, Frommhold D, Apel A, Mattern J, et al. VEGF expression by mesenchymal stem cells contributes to angiogenesis in pancreatic carcinoma. Br J Cancer 2008;99:622-31. https://doi.org/10.1038/sj.bjc.6604508

63. Razban V, Lotfi AS, Soleimani M, Ahmadi H, Massumi M, Khajeh $\mathrm{S}$, et al. HIF-1 $\alpha$ overexpression induces angiogenesis in mesenchymal stem cells. Biores Open Access 2012;1:174-83. https://doi. org/10.1089/biores.2012.9905

64. Crisan M, Yap S, Casteilla L, Chen CW, Corselli M, Park TS, et al. A perivascular origin for mesenchymal stem cells in multiple human organs. Cell Stem Cell 2008;3:301-13. https://doi.org/10.1016/ j.stem.2008.07.003

65. Chow L, Johnson V, Impastato R, Coy J, Strumpf A, Dow S. Antibacterial activity of human mesenchymal stem cells mediated directly by constitutively secreted factors and indirectly by activation of innate immune effector cells. Stem Cells Transl Med 2020;9:235-49. https://doi.org/10.1002/sctm.19-0092

66. Krasnodembskaya A, Song Y, Fang X, Gupta N, Serikov V, Lee $\mathrm{JW}$, et al. Antibacterial effect of human mesenchymal stem cells is mediated in part from secretion of the antimicrobial peptide LL-37. Stem Cells 2010;28:2229-38. https://doi.org/10.1002/stem.544

67. Lichtman MK, Otero-Vinas M, Falanga V. Transforming growth factor beta (TGF- $\beta$ ) isoforms in wound healing and fibrosis. Wound Repair Regen 2016;24:215-22. https://doi.org/10.1111/wrr.12398

68. Le Blanc K, Rasmusson I, Sundberg B, Götherström C, Hassan M, Uzunel M, et al. Treatment of severe acute graft-versus-host disease with third party haploidentical mesenchymal stem cells. Lancet 
2004;363:1439-41. https://doi.org/10.1016/S0140-6736(04)161047

69. Duijvestein M, Vos AC, Roelofs H, Wildenberg ME, Wendrich $\mathrm{BB}$, Verspaget HW, et al. Autologous bone marrow-derived mesenchymal stromal cell treatment for refractory luminal Crohn's disease: results of a phase I study. Gut 2010;59:1662-9. https://doi. org/10.1136/gut.2010.215152

70. Liang J, Zhang H, Wang D, Feng X, Wang H, Hua B, et al. Allogeneic mesenchymal stem cell transplantation in seven patients with refractory inflammatory bowel disease. Gut 2012;61:468-9. https:// doi.org/10.1136/gutjnl-2011-300083

71. Horwitz EM, Prockop DJ, Gordon PL, Koo WW, Fitzpatrick LA, Neel MD, et al. Clinical responses to bone marrow transplantation in children with severe osteogenesis imperfecta. Blood 2001;97:1227-31. https://doi.org/10.1182/blood.v97.5.1227

72. Sun JM, Kurtzberg J. Cell therapy for diverse central nervous system disorders: inherited metabolic diseases and autism. Pediatr Res 2018;83:364-71. https://doi.org/10.1038/pr.2017.254

73. Rosset P, Deschaseaux F, Layrolle P. Cell therapy for bone repair. Orthop Traumatol Surg Res 2014;100(1 Suppl):S107-12. https:// doi.org/10.1016/j.otsr.2013.11.010

74. Dohan DM, Choukroun J, Diss A, Dohan SL, Dohan AJ, Mouhyi $\mathrm{J}$, et al. Platelet-rich fibrin (PRF): a second-generation platelet concentrate. Part I: technological concepts and evolution. Oral Surg Oral Med Oral Pathol Oral Radiol Endod 2006;101:e37-44. https:// doi.org/10.1016/j.tripleo.2005.07.008

75. Dohan Ehrenfest DM, Pinto NR, Pereda A, Jiménez P, Corso MD, Kang BS, et al. The impact of the centrifuge characteristics and centrifugation protocols on the cells, growth factors, and fibrin architecture of a leukocyte- and platelet-rich fibrin (L-PRF) clot and membrane. Platelets 2018;29:171-84. https://doi.org/10.1080/0953 7104.2017.1293812

76. Fernando de Almeida Barros Mourão C, Calasans-Maia MD, Del Fabbro M, Le Drapper Vieira F, Coutinho de Mello Machado R, Capella $\mathrm{R}$, et al. The use of platelet-rich fibrin in the management of medication-related osteonecrosis of the jaw: a case series. J Stomatol Oral Maxillofac Surg 2020;121:84-9. https://doi.org/10.1016/ j.jormas.2019.02.011

77. Barbanti SH, Santos AR Jr, Zavaglia CA, Duek EA. Poly( $\varepsilon-$ caprolactone) and poly(D,L-lactic acid-co-glycolic acid) scaffolds used in bone tissue engineering prepared by melt compressionparticulate leaching method. J Mater Sci Mater Med 2011;22:237785. https://doi.org/10.1007/s10856-011-4398-0

78. Zheng P, Yao Q, Mao F, Liu N, Xu Y, Wei B, et al. Adhesion, proliferation and osteogenic differentiation of mesenchymal stem cells in 3D printed poly- $\varepsilon$-caprolactone/hydroxyapatite scaffolds combined with bone marrow clots. Mol Med Rep 2017;16:507884. https://doi.org/10.3892/mmr.2017.7266

79. Kuznetsov SA, Mankani MH, Leet AI, Ziran N, Gronthos S, Robey PG. Circulating connective tissue precursors: extreme rarity in humans and chondrogenic potential in guinea pigs. Stem Cells 2007;25:1830-9. https://doi.org/10.1634/stemcells.2007-0140

80. Takahashi K, Tanabe K, Ohnuki M, Narita M, Ichisaka T, Tomoda $\mathrm{K}$, et al. Induction of pluripotent stem cells from adult human fibroblasts by defined factors. Cell 2007;131:861-72. https://doi. org/10.1016/j.cell.2007.11.019

81. Liao HT, Chen CT. Osteogenic potential: comparison between bone marrow and adipose-derived mesenchymal stem cells. World J Stem Cells 2014;6:288-95. https://doi.org/10.4252/wjsc.v6.i3.288

82. Salgado AJ, Reis RL, Sousa NJ, Gimble JM. Adipose tissue derived stem cells secretome: soluble factors and their roles in regenerative medicine. Curr Stem Cell Res Ther 2010;5:103-10. https:// doi.org/10.2174/157488810791268564

83. Xin H, Katakowski M, Wang F, Qian JY, Liu XS, Ali MM, et al. MicroRNA cluster miR-17-92 cluster in exosomes enhance neuroplasticity and functional recovery after stroke in rats. Stroke 2017;48:747-53. https://doi.org/10.1161/ STROKEAHA.116.015204

84. Xie H, Wang Z, Zhang L, Lei Q, Zhao A, Wang H, et al. Extracellular vesicle-functionalized decalcified bone matrix scaffolds with enhanced pro-angiogenic and pro-bone regeneration activities. Sci Rep 2017;7:45622. https://doi.org/10.1038/srep45622

85. Li W, Liu Y, Zhang P, Tang Y, Zhou M, Jiang W, et al. Tissue-engineered bone immobilized with human adipose stem cells-derived exosomes promotes bone regeneration. ACS Appl Mater Interfaces 2018;10:5240-54. https://doi.org/10.1021/acsami.7b17620

86. Shi Q, Qian Z, Liu D, Sun J, Wang X, Liu H, et al. GMSC-derived exosomes combined with a chitosan/silk hydrogel sponge accelerates wound healing in a diabetic rat skin defect model. Front Physiol 2017;8:904. https://doi.org/10.3389/fphys.2017.00904

87. Shao L, Zhang Y, Lan B, Wang J, Zhang Z, Zhang L, et al. MiRNA-sequence indicates that mesenchymal stem cells and exosomes have similar mechanism to enhance cardiac repair. Biomed Res Int 2017;2017:4150705. https://doi.org/10.1155/2017/4150705

88. Park SR, Kim JW, Jun HS, Roh JY, Lee HY, Hong IS. Stem cell secretome and its effect on cellular mechanisms relevant to wound healing. Mol Ther 2018;26:606-17. https://doi.org/10.1016/ j.ymthe.2017.09.023

89. Filip S, Mokry J, Horacek J, English D. Stem cells and the phenomena of plasticity and diversity: a limiting property of carcinogenesis. Stem Cells Dev 2008;17:1031-8. https://doi.org/10.1089/ scd.2007.0234

90. Heslop JA, Hammond TG, Santeramo I, Tort Piella A, Hopp I, Zhou J, et al. Concise review: workshop review: understanding and assessing the risks of stem cell-based therapies. Stem Cells Transl Med 2015;4:389-400. https://doi.org/10.5966/sctm.2014-0110

91. Cyranoski D. Korean deaths spark inquiry. Nature 2010;468:485. https://doi.org/10.1038/468485a

92. Jung JW, Kwon M, Choi JC, Shin JW, Park IW, Choi BW, et al. Familial occurrence of pulmonary embolism after intravenous, adipose tissue-derived stem cell therapy. Yonsei Med J 2013;54:12936. https://doi.org/10.3349/ymj.2013.54.5.1293

93. Coppin L, Sokal E, Stéphenne X. Thrombogenic risk induced by intravascular mesenchymal stem cell therapy: current status and future perspectives. Cells 2019;8:1160. https://doi.org/10.3390/ cells 8101160

94. Stultz BG, McGinnis K, Thompson EE, Lo Surdo JL, Bauer SR, Hursh DA. Chromosomal stability of mesenchymal stromal cells during in vitro culture. Cytotherapy 2016;18:336-43. https://doi. org/10.1016/j.jcyt.2015.11.017

95. André T, Meuleman N, Stamatopoulos B, De Bruyn C, Pieters K, Bron D, et al. Evidences of early senescence in multiple myeloma bone marrow mesenchymal stromal cells. PLoS One 2013;8:e59756. https://doi.org/10.1371/journal.pone.0059756

96. Stagg J, Pommey S, Eliopoulos N, Galipeau J. Interferon-gammastimulated marrow stromal cells: a new type of nonhematopoietic antigen-presenting cell. Blood 2006;107:2570-7. https://doi. org/10.1182/blood-2005-07-2793

How to cite this article: Nifosì G, Nifosì L, Nifosì AF. Mesenchymal stem cells in the treatment of osteonecrosis of the jaw. J Korean Assoc Oral Maxillofac Surg 2021;47:65-75. https://doi. org/10.5125/jkaoms.2021.47.2.65 